\title{
Risks and benefits in the trial of the European Working Party on High Blood Pressure in the Elderly
}

\author{
Astrid Fletcher, Antoon Amery, Willem Birkenhäger, Christopher \\ Bulpitt, Denis Clement, Peter de Leeuw, Michel L. Deruyterre, \\ André de Schaepdryver, Colin Dollery, Robert Fagard, Françoise \\ Forette, Jill Forte, John-François Henry, Allan Koistinen, Gastone \\ Leonetti, Per Lund-Johansen, Auleki Nissinen, Eoin O'Brien, Kevin \\ O'Malley, Walter Pelemans, James Petrie, Jan Staessen, Laura Terzoli, \\ Lutgard Thijs, Jaakko Tuomilehto, John Webster and Brian Williams
}

\begin{abstract}
Hypertensive patients over the age of 60 years were admitted to a double-blind placebo-controlled trial. Patients in the actively treated group received a combined potassium-losing and -sparing diuretic (triamterene $50 \mathrm{mg}$ plus hydrochlorothiazide $25 \mathrm{mg} ; \mathrm{n}=416$ ); this dose could be doubled and methyldopa (up to $2 \mathrm{~g}$, daily) was added in $35 \%$ of patients when blood pressure remained high. The placebo group $(n=424)$ received matching capsules and tablets. Adverse effects were assessed in the double-blind period of the trial by calculating the incidence of abnormal biochemical results, investigator reports of diseases and prescriptions of concomitant therapy and a self-administered symptom questionnaire completed by patients. In 1000 hypertensive subjects over 60 years of age, 1 year of active treatment would prevent 11 fatal cardiac events, 6 fatal and 11 non-fatal strokes and 8 cases of severe congestive heart failure. No unexpected adverse treatment effects were observed. A significant excess incidence rate (per 1000 person years) was found in the active group compared with placebo for: (1) impaired renal function, a serum creatinine $>180 \mu \mathrm{mol} / /(2.0 \mathrm{mg} / \mathrm{dl})$; (2) mild hypokalaemia, a serum potassium $<3.5 \mathrm{mmol} /$; ; (3) reports of gout; and (4) an elevated serum uric acid $>0.52 \mathrm{mmol} / /$ in men or $>0.46$ in women. Elevated blood sugar and prescriptions for hypoglycaemic drugs tended to be more frequent in the actively treated group, but this difference was not statistically significant. In both grouns, there was a low incidence ( $<7$ per 1000 person years) of anaemia and depression and diseases of the liver, gall bladder or pancreas. More patients reported a dry mouth, blocked nose and diarrhoea in the active treatment group compared with placebo $(P<0.05)$. Dry mouth and diarrhoea were associated with methyldopa rather than diuretic. We conclude that the adverse effects do not outweigh the benefits of treatment in preventing stroke events, cardiac deaths and heart failure.
\end{abstract}

Journal of Hypertension 1991, 9:225-230

Keywords: Adverse effects, diuretics, methyldopa, hypertension.

From the European Working Party on High Blood Pressure in the Elderly (EWPHE) trial (see Appendix).

Sponsorship: This trial was carried out in consultation with the World Health Organization and supported by the Belgian National Research Foundation (NFWO) and the Belgian Hypertension Committee through a grant from Merck, Sharp \& Dohme and Smith, Kline \& French. These companies prepared Aldomet ${ }^{\circledR}$ tablets $\left(500 \mathrm{mg}\right.$ methyldopa) and Dyazide ${ }^{\circledR}$ capsules $(50 \mathrm{mg}$ triamterene and $25 \mathrm{mg}$ hydrochlorothiazide), and matching placebos. The drugs were processed under the supervision of $A$. De Maesschalck, pharmacist, with the advice of G. Van Herpe. Yearly meetings of the EWPHE were also sponsored by the European Economic Community, $\mathrm{ICl}$ and Astra Pharmaceuticals; J. Vanhollenbeke from Boehringer Pharma, Brussels, Belgium, collaborated in performing the quality control.

Requests for reprints to: Dr A. Fletcher, Epidemiology Research Unit, Division of Geriatric Medicine, Department of Medicine, Royal Postgraduate Medical School, Hammersmith Hospital, Du Cane Road, London, W12 OHS, UK.

Date of receipt: 27 March 1990; revised: 3 October 1990. 


\section{Introduction}

The European Working Party on High Blood Pressure in the Elderly (EWPHE) carried out a double-blind randomized placebo-controlled trial of antihypertensive treatment in 840 patients over the age of 60 . The principal results have been published previously [1] and showed a significant reduction in cardiovascular mortality in the actively treated group compared with placebo. Subsequent analyses showed that these reductions applied to both men and women but decreased with advancing age, with minimal treatment effect shown in patients over the age of 80 years [2]. However, a comprehensive assessment of the benefits of treatment requires that adverse effects are also considered. These may range from an increased morbidity to symptomatic side effects. In this paper, we present the results of analyses of adverse effects.

\section{Methods}

The study protocol has previously been published in detail [3]. In summary, patients aged over 60 years, with a sitting blood pressure on placebo within $160-239 \mathrm{mmHg}$ systolic and $90-119 \mathrm{mmH}$ diastolic, were randomized to double-blind treatment. In the active treatment group $(n=416)$, therapy started with a capsule of a diuretic $(50 \mathrm{mg}$ triamterene plus $25 \mathrm{mg}$ hydrochlorothiazide, daily); after 2 weeks, the dose could be increased to two capsules per day and, if the blood pressure remained high after 1 month, methyldopa tablets $(500 \mathrm{mg}$ ) were added, starting with half a tablet daily and increasing to four tablets daily. In the placebo group $(n=424)$, placebo capsules and tablets were matched to active treatment in taste, shape and colour.

Information on concomitant diseases and symptoms was recorded at entry to the study and at yearly intervals, and coded according to the 8th Revision of the International Classification of Diseases (ICD) [4]. Details of concomitant non-antihypertensive therapies and routine laboratory values were available at entry and at 3-monthly intervals throughout the trial. Drug therapy was coded both by generic name and class of therapy. All coding was blind to the randomized treatment. This information on disease, symptoms and therapy was also recorded when the patient left the trial, either at the time of its termination in July, 1984, or for a study-terminating event or defaulted from follow up.

Patients were asked to complete a questionnaire at entry and at each yearly visit. All questions had been published previously and were shown to be sensitive either to changes in blood pressure or to be associated with antihypertensive drug treatment [5-7]. Questions on the following symptoms were included: faintness, sleepiness, hours of sleep, weakness in the limbs, a slowed walking pace, headache, blurred vision, depression, diarrhoea, nocturia, dry mouth, nasal stuffiness, nausea, poor mental concentration and vivid dreams. Where appropriate, the questions had a time duration of the preceding 3 months and were translated from English into the various European languages, then translated back by a person who had not seen the original English version until an acceptable agreement was obtained.

Two countries and four centres within other countries did not collect questionnaire data. The countries with patients completing questionnaires were Finland, United Kingdom, Belgium, Italy, The Netherlands, Ireland, Portugal and Federal Republic of Germany.

\section{Method of analysis}

The incidence of diseases was established as follows. At entry to the trial, ICD codes were examined and only patients with no record of the particular ICD code were included, i.e. the analysis was restricted to 'new' cases. All follow up record forms for each patient, including the study termination form and death certificate when appropriate, were examined for the specific ICD code. The first ICD code entry was taken as the initiation of the disease or symptom. The number of patient years until the first event was recorded for each patient. For patients with no event, the total number of person years in the trial was recorded. Incidence rates were calculated in the usual manner, as the number of events per person years at risk. Prescription rates for non-antihypertensive therapy and incidence rates for abnormal laboratory values were also established in this way, taking only the first record of a particular prescription or an abnormal value.

Incidence rates for various diseases, symptoms and prescriptions were compared according to the randomized group, using rate differences and their $95 \%$ confidence intervals. The analysis was an 'on randomized treatment' analysis, not an 'intention to treat analysis' as data were not available for the latter. The questionnaire data were analysed according to the prevalence of symptoms at given time intervals according to randomized treatment.

\section{Results}

Incidence of disease during the trial

Conditions occurring wiih a rate $>5$ per 1000 person years in either treatment group are given in Table 1 . An excess of clinical reports of gout $(F<0.05)$ was found in the actively treated group. Diabetes was also more common, but the $95 \%$ confidence intervals inciuded zero rate difference. Clinical reports of headache were significantly fewer in the actively treated group $(P<0.01)$. The investigators tended to report depression more frequently in the actively treated group, an increase of 7 per 1000 person years $(95 \%$ confidence interval, -0.5 to +13.9 ). Both the active and placebo treatment groups had similar rates for malignant neoplasms ( $<20$ per 1000 person years), fractures (12 per 1000 person years) and diseases of the stomach and gall bladder ( $<7$ per 1000 person years). Anaemia, Parkinsonism, disorders of the pancreas and liver disease had an incidence of $<5$ per 1000 person years.

Incidence of abnormal laboratory biochemical values As shown in Table 2, in the active treatment group, the rates of elevated serum uric acid and serum creatinine and low serum potassium were higher $(P<0.001)$ than in placebo-treated patients. Abnormal glucose tolerance 
Table 1. Incidence of disease (ICD 8th revision) by randomized treatment.

\begin{tabular}{|c|c|c|c|c|c|}
\hline \multirow{3}{*}{$\begin{array}{l}\text { Disease (ICD codes) } \\
\text { All malignant neoplasms (1400-2090) }\end{array}$} & \multicolumn{2}{|c|}{ Rates per 1000 person years } & & & \\
\hline & Active (n) & Placebo (n) & \multicolumn{3}{|c|}{ Rate difference, $A-P(95 \% \mathrm{Cl})$} \\
\hline & $14.6(20)$ & 17.8 & -3.2 & $(-13.0$ & $+6.6)$ \\
\hline Diabetes mellitus (2500) & $22.4 \quad(29)$ & $16.2(20)$ & +6.2 & $(-4.8$ & $+17.2)$ \\
\hline Fractures $(8000-8299)$ & 12.5 & $12.3(15)$ & +0.2 & $(-4.34$ & $+4.4)$ \\
\hline Disorders of stomach (5310-5369) & 7.4 (10) & $5.8 \quad(7)$ & +1.6 & $(-4.7$ & $+7.9)$ \\
\hline Gout $(2740)$ & 5.1 (7) & $0.8 \quad(1)$ & $+4.3^{*}$ & $1+0.2$ & $+8.4)$ \\
\hline Dementia (2990) & $5.8 \quad(8)$ & $2.4 \quad(3)$ & +3.4 & $(-1.5$ & $+8.3)$ \\
\hline Gall bladder $(5740-5760)$ & $3.7 \quad(5)$ & 5.7 & -2.0 & $(-7.3$ & $+3.3)$ \\
\hline Headache $(7910)$ & $0.7 \quad(1)$ & 6.4 & $-5.7^{* *}$ & $(-10.3$ & $-1.1)$ \\
\hline Dizziness (7805) & $7.4(10)$ & 5.7 & +1.7 & $(-4.5$ & $+7.9)$ \\
\hline Depression (7902) & 14.0 & $7.3 \quad(9)$ & +6.7 & $(-0.5$ & $+13.9)$ \\
\hline
\end{tabular}

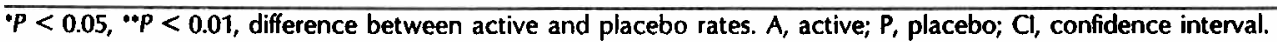

test results tended to occur more frequently on active treatment.

\section{Incidence of concomitant drug treatment}

The incidence of concomitant drug treatment was similar in the placebo- and active-treatment groups for most drugs, with the exception of $\beta$-blockers for short-term use ( $<3$ months), which were prescribed less frequently in the active group; 5 per 1000 person years on active treatment compared with 13 per 1000 person years on placebo $(P<0.05)$. Again, a tendency for diabetes to be more common on active treatment was reflected in an increase in hypoglycaemic drugs; 22 per 1000 person years on active treatment compared with 15 per 1000 person years on placebo (95\% confidence intervals for the difference, -4 to +17$)$.

\section{Questionnaire data}

Response rates were calculated for the participating centres overall, and by treatment type and sex.

The response rate was $59 \%$ at 1 year, $61 \%$ at 2 years and $64 \%$ at 3 years. The number of patients declined with length of follow up (due to deathis, withdrawals and stopping of the trial), so that $\stackrel{5}{\leftarrow} 5$ years, questionnaire data were available for 113 out of 178 patients. Data for years 4 and 5 after entry have not, therefore, been presented due to the small number of questionnaires in each treatment group.

Since other workers have shown that women tend to have higher reporting rates for symptoms, it was important to check for bias in the questionnaire data, occurring due to a differential response rate by men and women in the treatment groups. A very similar response rate for men and women was found.

Table 3 shows the prevalence of symptoms in the activeand placebo-treatment groups up to year 3. Certain symptoms were significantly more common on active treatment than placebo: a dry mouth (and the complaint that this symptom interfered with eating), nasal stuffiness and diarrhoea.

Symptoms significantly associated with active treatment were further investigated by comparing patients on active diuretic with those on active diuretic plus methyldopa at years 1, 2 and 3. A dry mouth was significantly related to treatment with methyldopa plus diuretic (57\% at year 1 and $60 \%$ at year 3$)$ compared with diuretic only $(27 \%$ at year 1 and $40 \%$ at year $3 ; P<0.001$ and $P<0.05$, respectively). A dry mouth interfering with eating was reported consistently higher by patients on methyldopa plus diuretic (23\%, 20\% and 19\% at years 1,2 and 3 , re-

Table 2. Incidence of abnormal biochemical values.

Rates per 1000 person years

\begin{tabular}{|c|c|c|c|c|c|}
\hline A'onormal values & Active (n) & Placebo (n) & \multicolumn{3}{|c|}{ Rate difference, A-P $(95 \% \mathrm{Cl}$} \\
\hline \multicolumn{6}{|l|}{ Serum uric acid } \\
\hline$>0.52 \mathrm{mmol} / \mathrm{l} \mathrm{men},>0.46 \mathrm{mmol} / \mathrm{l}$ women & $79.3 \quad(85)$ & $12.7 \quad(14)$ & $+66.6^{* *}$ & $1+48.5$ & $+84.8)$ \\
\hline \multicolumn{6}{|l|}{ Glucose tolerance test } \\
\hline Blood sugar $>10 \mathrm{mmol} / \mathrm{l}$ (both at 1 and $2 \mathrm{~h}$ ) & $29.5 \quad(23)$ & 20.2 & +9.3 & $(-6.5$ & $+25.1)$ \\
\hline \multicolumn{6}{|l|}{ Serum creatinine } \\
\hline$\geq 180 \mu \mathrm{mol} / /(2.0 \mathrm{mg} / \mathrm{dl})$ & 33.3 & $9.8 \quad(12)$ & $+23.4^{*}$ & $(+11.8$ & $+35.0)$ \\
\hline$\geq 220 \mu \mathrm{mol} / \mathrm{l}(2.5 \mathrm{mg} / \mathrm{dl})$ & $8.3 \quad(11)$ & $5.8 \quad(7)$ & +2.5 & $(-4.0$ & $+9.0)$ \\
\hline$\geq 365 \mu \mathrm{mol} / 1(3.0 \mathrm{mg} / \mathrm{dl})$ & $1.5 \quad(2)$ & 1.6 & -0.1 & $(-4.1$ & $+3.0)$ \\
\hline \multicolumn{6}{|l|}{ Serum potassium } \\
\hline$>5.0 \mathrm{mmol} / \mathrm{l}$ & $38.4 \quad(48)$ & $50.1 \quad(54)$ & -11.7 & $(-33.3$ & $+3.3)$ \\
\hline$<3.5 \mathrm{mmol} / \mathrm{l}$ & 115.8 (122) & $45.1 \quad(50)$ & $+70.8^{* *}$ & $(+46.7$ & $+94.8)$ \\
\hline
\end{tabular}

${ }^{\circ} \mathrm{P}<0.001, \cdots P<0.0001$, difference between active and placebo rates. $\mathrm{A}$, active; $\mathrm{P}$, placebo; $\mathrm{Cl}$, confidence interval. 
Table 3. Prevalence of symptom reporting $(\%)$.

\begin{tabular}{|c|c|c|c|c|c|c|}
\hline \multirow[b]{2}{*}{ Symptoms } & \multicolumn{3}{|c|}{ Active } & \multicolumn{3}{|c|}{ Placebo } \\
\hline & $\begin{array}{c}1 \text { year } \\
(n=150)\end{array}$ & $\begin{array}{c}2 \text { years } \\
(n=129)\end{array}$ & $\begin{array}{c}3 \text { years } \\
(n=113)\end{array}$ & $\begin{array}{c}1 \text { year } \\
(n=138)\end{array}$ & $\begin{array}{c}2 \text { years } \\
(n=111)\end{array}$ & $\begin{array}{l}3 \text { years } \\
(n=82)\end{array}$ \\
\hline Dry mouth ${ }^{\dagger}$ & 37 & $41^{\circ}$ & $48^{* *}$ & 34 & 25 & 26 \\
\hline Dry mouth interferes with eatingt & 12 & $14^{\bullet}$ & 12 & 8 & 6 & 5 \\
\hline Vivid dreams & 22 & 24 & 25 & 26 & 21 & 16 \\
\hline Poor concentration & 10 & 12 & 7 & 11 & 10 & 9 \\
\hline Slower walking pace & 30 & 30 & 28 & 29 & 31 & 20 \\
\hline Sleepiness & 34 & 31 & 29 & 31 & 32 & 32 \\
\hline Faintness & 31 & 27 & 26 & 29 & 23 & 24 \\
\hline Depression & 22 & 18 & 23 & 26 & 17 & 15 \\
\hline Weak limbs & 32 & 30 & 26 & 31 & 28 & 32 \\
\hline Blurred vision & 27 & 25 & 23 & 25 & 29 & 24 \\
\hline Nasal Stuffiness & $32^{\circ}$ & 24 & 22 & 21 & 23 & 18 \\
\hline Nausea & 9 & 13 & 5 & 7 & 13 & 15 \\
\hline Diarrhoea ${ }^{\dagger}$ & $28^{\circ}$ & 24 & 23 & 18 & 18 & 20 \\
\hline Headache & 30 & 29 & 25 & 33 & 36 & 30 \\
\hline
\end{tabular}

$\cdot p<0.05, * P<0.01$, versus placebo; $f$, mainly associated with methyldopa; $n$, number of questionnaires completed by year and treatment group.

spectively) compared with diuretic alone $(6 \%, 11 \%$ and $8 \% ; P<0.05)$. Diarrhoea was also associated more with methyldopa plus diuretic $(36 \%, 30 \%$ and $34 \%$ at years 1 , 2 and 3 , respectively) compared with diuretic only (25\%, $21 \%$ and $16 \% ; P<0.05$ at year 3 ).

\section{Discussion}

Overall, no unexpected side effects of active treatment were found. Hypokalaemia, glucose intolerance and increased serum uric acid and creatinine levels have frequently been reported in elderly patients treated with diuretics [8-11] and in interim reports from this trial $[12,13]$. The importance of the data presented in this paper is the quantification of adverse drug effects which allows the 'Overall Balance Sheet' to be drawn up. The problem remains of comparing important benefits with adverse effects of treatment that range from the relatively trivial to more serious. Table 4 shows that in 1000 hypertensive subjects over 60 years of age, 1 year of treatment with triamterene plus hydrochlorothiazide, and with additional methyldopa in one-third, would prevent 11 fatal cardiac events, 6 fatal and 11 non-fatal strokes and 8 cases of severe congestive heart failure. However, active treatment was also associated with four clinical reports of gout, nine of diabetes (an abnormal glucose tolerance test), 23 of an elevated serum creatinine $\geq 180 \mu \mathrm{mol} / 1,71$ of mild hypokalaemia (serum potassium $<3.5 \mathrm{mmol} / \mathrm{l}$ ), 71 self-reports of diarrhoea and 124 of dry mouth. Most would agree that the benefits of treatment outweigh the disadvantages, but the adverse effects must be considered further.

Hyperuricaemia is a risk factor for gout and in the IEWPHE trial an excess of clinical gout was reported on active treatment, 4 cases per thousand person years. The relationship of hyperuricaemia to renal disease is not clear; renal function may be impaired by hyperuricaemia, or hyperuricaemia may be a consequence of impaired renal function. Renal stones have been found in 4-73\% of patients with hyperuricaemia including those without gout [14]. It has also been suggested that triamterene may independently contribute to the formation of renal stones [15-17] although Jick et al. [18] found no ev:dence of an increased incidence of urinary stones in a large epidemiological study relating hospital admissions for this condition to prescription use. No cases of renal stones were reported in the EWPHE trial although the presence of asymptomatic stones cannot be excluded.

Table 4. Difference between active and placebo treatment in $1000 \mathrm{pa}$ tients treated for 1 year.

Numbers

$\begin{array}{lc}\text { Benefit } & \\ \text { Fatal cardiac events } & -11^{*} \\ \text { Fatal cerebrovascular events } & -6 \\ \text { Non-fatal cerebrovascular events } & -11^{\circ} \\ \text { Severe congestive heart failure } & -8^{*} \\ \text { Risk (adverse effects) }{ }^{\circ} & \\ \text { Gout } & +4^{\circ} \\ \text { Mild hypokalaemia }\left(\mathrm{K}^{+}<3.5 \mathrm{mmol} / \mathrm{l}\right) & +71^{\circ * *} \\ \text { Abnormal serum creatinine } \geq 180 \mu \mathrm{mol} / \mathrm{l}(2 \mathrm{mg} / \mathrm{d}) & +23^{\circ *} \\ \text { Diabetes } & +9 \\ \text { Dry mouth } & +124^{\circ *} \\ \text { Diarrhoea } & +71^{*}\end{array}$

$\cdot p<0.05, \cdots p<0.001, \cdots p<0.0001$, difference between active and placebo rates. $t$; A full description of these conditions is given in the text. Adverse effects were considered to be associated with diuretic treatment, with the exception of $\mathrm{dry}$ mouth and diarrhoea which were mainly associated with methyldopa.

Deteriorating renal function on active treatment was also shown by an average rise of $15 \mu \mathrm{mol} / \mathrm{l}$ in serum creatinine compared with no change in the placebo group. The incidence of abnormally high creatinine levels, $\geq 180 \mu \mathrm{mol} / \mathrm{l}$ $(2 \mathrm{mg} / \mathrm{dl})$, occurred in 42 patients on active treatment compared with 12 on placebo, an excess rate of 23 per thousand person years, $(P<0.0001)$. There was a ten- 
dency for these levels to be sustained. Of the 42 active patients with a reading during the trial of $\geq 180 \mu \mathrm{mol} / 1$ $(2 \mathrm{mg} / \mathrm{dl}), 21 \mathrm{had}$ at least one further reading during the trial of this value or above, 10 patients had a further reading of $\geq 130 \mu \mathrm{mol} / \mathrm{l}(1.5 \mathrm{mg} / \mathrm{dl})$ and 11 patients had no further readings. Similarly, of the 12 placebo patients with a creatinine level $\geq 180 \mu \mathrm{mol} / 1(2 \mathrm{mg} / \mathrm{dl}), 8$ patients had at least one further reading of this value or over and three patients had readings of $\geq 130 \mu \mathrm{mol} / \mathrm{l}(1.5 \mathrm{mg} / \mathrm{dl})$. However, considering all patients, in only two on active treatment and two on placebo did serum creatinine levels rise as high as $\geq 265 \mu \mathrm{mol} / \mathrm{l}(3 \mathrm{mg} / \mathrm{dl})$. A protocol withdrawal criteria was an increase of serum creatinine of $\geq 100 \%$. Five patients on active treatment and one on placebo were withdrawn for this reason. One patient on active treatment and none on placebo died from renal disease.

Despite the use of potassium-sparing diuretic, potassium levels fell in the actively treated group. An increased incidence of abnormally low potassium values $(<3.5 \mathrm{mmol} / \mathrm{l})$ was found in 122 patients on active treatment compared with 50 on placebo, an excess rate of 71 cases per thousand person years. The prognostic signifcance of hypokalaemia remains uncertain. In a substudy of the Medical Research Council (MRC) trial, ventricular ectopic beats were found to be significantly higher in those receiving long-term thiazide treatment than their age- and sex-matched controls [19]. Short-term treatment with bendrofluazide alone did not increase the number of extra systoles, but a lower ectopic rate was observed in the group treated with bendrofluazide plus potassium supplementation for the same period. The overall results of the MRC trial did not show any important increase in cardiac mortality as a result of diuretic treatment. The relative risk for sudden death in men receiving bendrofluazide was 1.4 compared with placebo (95\% confidence interval, 0.8-2.3) and, in the first year of treatment, 3.4 (95\% confidence interval, 0.9-15.4) [20], and Miall and Greenberg [20] suggested that any possible coronary hazard from thiazide diuretics was concentrated in the first year. No adverse effect on cardiac events in activelytreated patients was seen in the EWPHE trial; moreover, cardiac mortality was significantly reduced on active treatment. It is possible that this difference in diuretic effect was due to a lower level of potassium depletion in the EWPHE trial (reduction of $0.2 \mathrm{mmol} / \mathrm{l}$ ) compared with a reduction by bendrofluazide of $0.6 \mathrm{mmol} / \mathrm{l}$ in the MRC trial.

We have previously described a deterioration in glucose tolerance on active treatment compared with placebo [11] in all patients entering the trial. The present analysis excluded patients with glucose intolerance at entry and showed a small but non-significant deterioration with active treatment. Moreover, fasting glucose levels rose on average by $5 \mathrm{mg} / \mathrm{dl}$ on active treatment compared with no change on placebo [12]. The clinical importance of these increases can be judged from the incidence of physician reports of diabetes and the number of new prescriptions for hypoglycaemic drugs. There were 29 physician reports of diabetes on active treatment and 20 on placebo, a rate excess of 6 per 1000 patient years on active treat- ment ( $95 \%$ confidence interval, -5 to +17 ). Similarly, 28 patients on active treatment received a new prescription for hypoglycaemic drugs compared with 18 in the placebo group, a rate excess of 6.7 per 1000 patient years (95\% confidence interval, -4 to +17$)$. These data suggest that the consequence of a rise in glucose on active treatment is an annual excess of 6 patients in 1000 developing diabetes considered worthy of treatment, while including untreated abnormal glucose tolerance tests gives an excess rate of 9 cases.

There was no evidence of an excess of diseases of the gall bladder, pancreas or liver with active treatment. Other studies have provided conflicting evidence on the association between thiazide diuretic use and increased risk of cholecystitis [21-23]. Pancreatitis has also been reported as an adverse effect of thiazide treatment $[24,25]$ and liver damage with methyldopa [26,27].

Clinical reports of iron-deficiency anaemia occurred at a similar rate in both groups. No case of haemolytic anaemia or thrombocytopenia was reported in the present trial.

The incidence of cancer was similar on both active and placebo treatment. The rates were comparable to those described for the community [28]. This does not agree with other data where hypertensives had lower cancer rates than the general population [29].

An excess of two well known side effects of methyldopa was reported: dry mouth and diarrhoea. A comparison with either placebo or diuretic showed no increase of sleepiness, nocturia or weak limbs, occurrences which have been recorded in other studies with methyldopa [30].

In long-term randomized trials, double-blinding, such as in the EWPHE trial, allows a more accurate assessment of adverse events in contrast to single-blind trials where it is difficult to ascribe adverse consequences of treatment impartially due to investigator bias. Moreover, adverse effects reported in most trials are based on prevalence data. In the present trial, the calculation of incidence rates (of abnormal laboratory values, investigator reporting of new diseases and concomitant medication) provides a more valid measure of the magnitude of treatment effects compared with placebo.

\section{Acknowledgements}

The authors wish to thank the many elderly hypertensive patients who freely consented to take part in the trial. They also gratefully acknowledge the clerical and technical assistance of Mrs V. Mariën, Mrs Y. Toremans and Mrs S. Van Hulle.

\section{References}

1. AMERY A, BIRKENHĀGER W, BRTXKo R, ET AL: Mortality and morbidity results from the European Working Party on High blood pressure in the Elderly trial Lancet 1985, 1:1349-1354.

2. AMERY A, BiRKENHÄGER W, BRIXKO R, ET AL: Efficacy of antihypertensive drug treatment according to age, sex, blood 
pressure, and previous cardiovascular disease in patients over the age of 60 . Lancet 1986, ii:589-591.

3. EUROPEAN WORKING PARTY ON HIGH BLOOD PRESSURE IN THE ELDERLY (EWPHE): An International Trial of Antihypertensive Therapy in Elderly patients. Objectives, protocol and organization. Arch Int Pharmacodyn 7ber 1985, 2:300-334.

4. Manual of the International Statistical Classification of diseases, injuries and causes of death. Based on the recom. mendations of the Eighth Revision Conference. Geneva: World Health Organization, 1967.

5. ButprTt CJ, DOLerY CT: Side effects of hypotensive agents evaluated by a self-administered questionnaire. Br Med J 1973, 3:485-490.

6. BulptTT CJ, DOLLERY CT, CARNe S: A symptom questionnaire for hypertensive patients. J Chron Dis 1974, 27:309-323.

7. Bulpitr CJ, DOLlery CT, CARne S: Change in symptoms of hypertensive patients after referral to hospital clinic. $\mathrm{Br}$ Heart $J$ 1976, 2:121-128.

8. Borland C, Amad A, Murphy P, Shalicross T: Biochemical and clinical correlates of diuretic therapy in the elderly. Age Ageing 1986, 15:357-363.

9. MaCLEnNAN WJ: Diuretics in the elderly: how safe? [Editorial]. $\mathrm{Br}$ Med J 1988, 296:1551.

10. BALEY RR: Adverse renal reactions to non-steroidal antiinflammatory drugs and potassium-sparing diuretics. $A d$ verse Drug React Bull 1988, 131:492-495.

11. Wikstrand J, Westergren G, Berlund G, et al: Antihypertensive treatment with metoprolol or hydrochlorothiazide in patients aged 60 to 75 years. JAMA 1986, 255:1304-1309.

12. THE EUROPEAN WORKING PARTY ON HIGH BLOOD PRESSURE IN THE ELDERLY (EWPHE): Antihypertensive therapy in elderly patients. Neth J Med 1984, 27:165-170.

13. AMERY A, BIRKENHÄGER W, BLXKO P, ET AL: Glucose intolerance during diuretic therapy in elderly hypertensive patients. A second report from the European Working Party on High blood pressure in the Elderly (EWPHE). Postgrad Med J 1986, 62:919-924.

14. SCOTT JT: Asymptomatic hyperuricaemia. Br Med J 1987, 294:987-988.

15. FAIRIEY KF, BIRCH DF, HAINES I: Abnormal urinary sediment in patients on triamterene. Lancet 1983, i:421-422.

16. ETIINGER B, OIDROYD NO, SORGEL F: Triamterene nephrolithiasis. JAMA 1980, 244:2443-2445.

17. SORGel F, ETtinger B, Benet LZ: The true composition of kidney stones passed during triamterene therapy. $J$ Urol 1985, 134:871-873.

18. JICK H, DINAN BJ, HUNTER JR: Triamterene and renal stones. J Urol 1982, 127:224-225.

19. Medical RESEARCH COUNCIL WORKIng PaRTY ON MILD to MODERATE HYPERTENSION: Ventricular extrasystoles during thiazide treatment: substudy of the MRC mild hypertension trial. $\mathrm{Br}$ Med $J$ 1983, 287:1249-1253.

20. Miall WE, GreenberG G: Mild bypertension - is there pres sure to treat? An account of the MRC trial. Cambridge: Cambridge University Press, 1987, pp 114-115.

21. Rosenberg L, Shapiro S, Slone D, Kaufman DW, Mietrinen OS, STOLEY PD: Thiazides and acute cholecystitis. $N$ Eng $J$ Med 1980, 303:546-548.

22. LINDEN W, RTTIER B, EDLUND G: Acute cholecystitis and thiazides. Br Med J 1984, 289:654-655.

23. KAKAR F, WEISS NS, STRITE SA: Thiazide use and the risk of cholecystectomy in women. Am J Epidemiol 1986, 124:428-433.

24. CORNISH AL, MCCLELAN JT, JOHNSTON DH: Effects of chlorothiazide on the pancreas. $N$ Engl J Med 1961, 265:673-675.

25. ECKHAUSER ML, DOKIER MA, IMBEMBO AL: Diuretic-associated pancreatitis: a collective review and illustrative cases. $\mathrm{Am}$ $J$ Gastroenterol 1987, 82:865-869.

26. TOGHLL. PJ, SMITH PG, BENTON P, BROWN RC, MATTHEWS HL: Methyldopa liver damage. $\mathrm{Br}$ Med $J$ 1974, 3:545-548.

27. DEBARD ML: Methyldopa reaction simulating septic shock. Arch Int Med 1979, 139:196-197.
28. OfFice OF POPULATION CONSENSUS AND SuRveys Cancer STATISTICS: Incidence, survival and mortality in England and Wales. Studies on Medical and Population Subjects No 43. London: HMSO, 1981.

29. BuipitT CJ, BEEvers G, ButLer A, ET AL: The survival of treated hypertensive patients and their causes of death: a report from the DHSS Hypertensive Care Computing Project (DHCCP). $J$ Hypertens 1986, 6:93-99.

30. CroOg SH, Levine S, TESTA M, ET aL: The effects of antihypertensive therapy on the quality of life. $N$ Engl $J$ Med 1986, 314:1657-1664.

\section{Appendix}

The following centres and individuals collaborated in the European Working Party on High Blood Pressure in the Elderly (EWPHE) trial: P. Lund-Johansen, O.J. Ohm, P. Omvik, University Hospital Haukeland, Bergen, Norway; A. Alasoini, A. Koistinen, A. Nissinen, P. Puska, J. Tuomilehto, R. Varis, North Karelia Project, Helsinki, Finland; W. Birkenhäger, P. de Leeuw, P. Willemse, Zuiderziekenhuis, Rotterdam, The Netherlands; K. Beard, J.L.C. Dall, the late J.P.R. MacFarlane, B.O. Williams, Victoria Geriatric Unit, Glasgow, Scotland; T.A. Jeffers, J.C. Petrie, O.J. Robb, J. Webster, Aberdeen Royal Infirmary, Aberdeen, Scotland; M. Laher, P. McCormack, F. Meagher, E. O'Brien, W. O'Callaghan, K. O'Malley, Royal College of Surgeons, Dublin, Ireland; C. Bulpitt, C. Dollery, A. Fletcher, P. Lewis, M. Murphy, Hammersmith Hospital, London, England; R.C. Hamdy, N.H. Perera, St. John's Hospital, London, England; X. Chellappah, J. Morris, A.I. Suchett-Kaye, St Charles' Hospital, London, England; H. Feltkamp, A. Konrads, U. Lasser, K Meurer, University Hospital, Köln, Federal Republic of Germany; A. Amery, R. Fagard, the late J. Hellemans, J.V. Joossens, P. Lijnen, W. Pelemans, j. Staessen, L. Thijs, R. Van Hoof, University Hospital, Gasthuisberg, Leuven, Belgium; M. Bogaert, D. Clement, A. De Schaepdryver. University Hospital, Ghent, Belgium; P. Brixko, the late A. Ernould, A. Mutsers, Geriatric Hospital Le Valdor, Liège, Belgium, J.F. De Plaen, Ch. van Ypersele, University Hospital St Luc, Bruxelles, Belgium; M. Deruyttere, Medisch Centrum voor Huisartsen, Leuven, Belgium; P. Berthaux, F. Forette, J.F. Henry, Hospital Charles Foix, Ivry, France; G. Leonetti, X. Tammaro, L. Terzoli, A. Zanchetti, Centro di Fisiologia Clinica e Ipertensione, Milano, Italy; F. de Padua, J. Forte, J.M. Pereira-Miguel, University Hospital Santa Maria, Lisboa, Portugal.

The EWPHE trial was co-ordinated by A. Amery, Leuven and A. De Schaepdryver,Ghent, Belgium.

The steering committee included A. Amery, A. De Schaepdryver, C. Dollery, J.V. Joossens and T. Strasser.

The publications committee included A. Amery, W. Birkenhäger, C. Bulpitt, A. De Schaepdryver and C. Dollery.

The advisors were E. Freis, the late F. Gross, M. Healy, S. Hoobler, P. Milliez and J. Willems. 